\title{
IDENTIFIKASI DAN DISTRIBUSI NYAMUK AEDES $S P$. SEBAGAI PREVALENSI PENYAKIT DEMAM BERDARAH DENGUE DI KABUPATEN KARO
}

\author{
Jernita Sinaga, Likasi Emita \\ Dosen Poltekkes Kemenkes Medan Jurusan Kesehatan Lingkungan \\ Email : jernitasinaga_74@yahoo.co.id
}

\begin{abstract}
ABSTRAK
Distribusi nyamuk Aedes sp. dipengaruhi oleh perubahan lingkungan. Aedes spi adalah nyamuk yang termasuk dalam subfamili Culicinae, famili Culicidae, ordo Diptera, kelas Insecta. Nyamuk ini berpotensi untuk menularkan penyakit demam berdarah dengue (DBD). DBD adalah suatu penyakit yang ditandai dengan demam mendadak, perdarahan baik di kulit maupun di bagian tubuh lainnya serta dapat menimbulkan syok dan kematian. Penyakit DBD ini terutama menyerang anak-anak termasuk bayi, meskipun sekarang proporsi penderita dewasa meningkat.

Kabupaten Karo memiliki potensi mengalami perubahan lingkungan yang dapat mengganggu karakteristik habitat normal genus nyamuk Aedes sp., sehingga perlu dilakukan penelitian. Penelitian ini bertujuan untuk mengetahui distribusi nyamuk Aedes $s p$. di Kabupaten Karo berdasarkan karakteristik habitat normalnya. Sampel penelitian adalah nyamuk genus Aedes sp yang ditemukan di dalam perangkap yang dipasang berdasarkan prevalensi penyakit DBD di Kabupaten Karo yaitu Kecamatan Kabanjahe, Kecamatan Berastagi dan Kecamatan Merek. Metode penelitian Explanatory Research bersifat deskriptif menarasikan perbedaan populasi semua nyamuk Aedes sp yang ditemukan di dalam perangkap yang dipasang di lokasi penelitian dan melakukan pemeriksaan laboratorium dengan tehnik identivikasi genus nyamuk Aedes sp., dan pengukuran karakteristik habitat normal nyamuk Aedes Aegipty dengan mengukur ketinggian lokasi, suhu udara lokasi, dan kelembaban.

Hasil penangkapan nyamuk Aedes $s p$ setelah di identivikasi di laboratorium di seluruh lokasi penangkapan diperoleh 106 ekor nyamuk yang yaitu Aedes Aegipty 6.77\% dan Aedes Abopiktus 5.09\%. Spesies yang paling banyak ditemukan adalah Aedes Aegipty yaitu sebanyak 59 ekor dan Aedes Albopiktus adalah 47 ekor, rata-rata ketingian daerah $1208.15 \mathrm{~m}$ dpl yang diukur di temukan nyamuk Aedes sp 8 ekor dengan rincian Aedes Aegipty 3 ekor dan Aedes Albopiktus 5 ekor. Species nyamuk Aedes sp terbanyak diketingian 913 - 1100 dengan jumlah nyamuk Aedes $s p$ adalah 32 ekor dengan rincian Aedes Aegipty 16 ekor dan Aedes Albopiktus 16 ekor,

Rata-rata suhu $27^{\circ} \mathrm{C}$ didapat nyamuk Aedes sp 61 ekor dengan rincian Aedes Aegipty 36 ekor dan Aedes Albopiktus 25 ekor dan species nyamuk Aedes sp terbanyak di dapat pada suhu $25,0^{\circ} \mathrm{C}-30,0^{\circ} \mathrm{C}$ ditemukan species nyamuk Aedes sp 61 ekor dengan rincian Aedes Aegipty 36 ekor dan Aedes Albopiktus 25 ekor, rata-rata kelembaban daerah $73,90^{\circ} \mathrm{F}$ dengan nyamuk Aedes $s p 65$ ekor. Species nyamuk Aedes $s p$ terbanyak di dapat pada kelembaban $60-80^{\circ} \mathrm{F}$, ditemukan 65 ekor nyamuk Aedes sp. dengan rincian Aedes Aegipty 37 ekor dan Aedes Albopiktus 28 ekor.
\end{abstract}

Kata Kunci: DBD, Aedes sp, Identifikasi. 
BAB I

PENDAHULUAN

\subsection{Latar Belakang}

Berdasarkan laporan program pemberantasan penyakit menular bersumber binatang (P2B2) Dinas Kesehatan Propinsi Sumatera Utara (2005) menunjukkan selama kurung waktu (2000-2004), jumlah kasus DBD cenderung berfluktuasi, dimana daerah endemis DBD selama kurung waktu tersebut adalah kota Medan, Binjai, Deli serdang, Langkat dan Asahan ditambah dengan daerah sporadis, yaitu kota Tebing Tinggi, Pematang Siantar dan Kabupaten Karo. IR DBD tahun 2003 sebesar 7,77 per 100.000 penduduk meningkat menjadi 8,79 per 100.000 tahun 2004. daerah yang termasuk daerah KLB adalah kota Medan dan Kabupaten Deli Serdang, dimana angka kematian (Case Fatality Rate) sebesar 2,20\%, hal ini mengindikasikan angka CFR tersebut melebihi dari indikator nasional, yaitu $1 \%$ (Dinkes Prop. Sumut,2005).

Hal ini diasumsikan bahwa terjadinya peningkatan mobilitas penduduk yang tinggi ke kota Medan, dan semakin berkembangnya trasportasi, hal tersebut tidak menutup kemungkinan virus dengue yang di bawah oleh orangorang yang terinfeksi yang bergerak atau berpindah tempat dari satu tempat ke tempat lain yang berpengaruh terhadap peningkatan kasus DBD, hal ini mengindikasikan bahwa sistem surveilans epidemiologi belum memadai, dimana belum adanya kewaspadaan dini, (Dinkes Pemkot Medan, 2003).

Dilihat dari penularan penyakit DBD salah satunya juga disebabkan oleh mobilitas penduduk, sehingga kemungkinan terjadinya pada masyarakat Kabupaten Karo. Kasus DBD di Kabupaten Karo pertama sekali ditemukan pada tahun 1997 pada seorang anak sekolah dasar (SD) di Kota Kabanjahe. Setelah dilakukan survei epidemiologi oleh pihak Dinas Kesehatan Kabupaten Karo ternyata anak tersebut beberapa hari sebelum gejala pertama muncul telah bepergian ke kota Medan, yaitu daerah endemis DBD.

Demikian juga kasus lain pada tahun tersebut sampai tahun 2003 semuanya terindikasi terjangkit di luar daerah Kabupaten Karo. Kecamatan 
Kabanjahe selama kurung waktu 2001-2005, jumlah kasus berfluktuasi, yaitu sebanyak 53 kasus tahun 2001 sebanyak 2 kasus, tahun 2002 meningkat menjadi 3 kasus, tahun 2003 menjadi 19 kasus dengan jumlah penderita meninggal 2 orang ( $C F R=10,5 \%$ ), tahun 2004 menurun menjadi 3 orang dan tahun 2005 meningkat drastis menjadi 26 kasus dimana kasus tertinggi terdapat di kelurahan gung negeri yaitu sebanyak 21 kasus (39,6\%), (Dinkes Kab Karo, 2005).

Berdasarkan hasil investigasi dan kajian epidemiologi yang di lakukan oleh Dinas Kesehatan Kabupatn Karo (2005) ternyata penderita tersebut tidak pernah keluar dari kota Kabanjahe sebelum gejala pertama muncul. Keadaan ini sangat mengejutkan mengingat kota Kabanjahe dan sekitarnya secara geografis berada pada ketingian diatas 1000 meter diatas permukaan laut, dimana secara teoritis keadaan ini jarang terjadi kasus DBD,. Nyamuk Ae. aegypti hidup di dataran rendah dengan iklim tropis sampai subtropis, nyamuk dapat berkembang biak dengan baik sampai ketinggian \pm 1000 meter, Ae. aegypti biasanya tidak ditemukan di daerah dengan ketinggian lebih dari 1000 meter karena biasanya daerah dengan ketinggian tersebut memiliki suhu udara yang rendah, sehingga tidak memungkinkan bagi nyamuk Ae. aegypti untuk hidup, hal tersebut prevalensi DBD banyak terjadi diketingian dibawah 1000 meter diatas permukaan laut. Dikabupaten Karo dengan ketingian 1000 meter diatas permukaan laut telah ditemukan penderita DBD.

Hal ini dapat menyebabkan Kabupaten Karo memiliki potensi mengalami perubahan lingkungan. Perubahan lingkungan tersebut akan menganggu habitat normal Aedes sp. dan menjadi resiko peningkatan potensi penularan virus dengue. Selain itu, perobahan kondisi lingkungan, suhu dan kelembaban kabupaten karo dapat mengalami perobahan kemungkinan akibat pemanfaatan lahan yang tidak terkendali juga dapat mempercepat perubahan dominasi vektor pembawa penyakit tular. Untuk mengetahui jenis nyamuk Aedes sp tersebut harus dilakukan identifikasi dan melihat perobahan lingkungan yang menyebabkan perkembangbiakan nyamuk di Kabupaten Karo. 
Pendidikan dan pengetahuan untuk mengetahui jenis nyamuk Aedes $s p$ tersebut perlu di lakukan Identifikasi nyamuk aedes $s p$ dengan dinamika populasi vektor sehingga dapat diketahui jenis nyamuk yang paling dominan pada daerah penelitian dan untuk mengetahui dampak dari perubahan lingkungan yang terjadi terhadap transmisi penyakit akibat vektor aedes $s p$. Meningkatnya kasus dengue di Kabupaten Karo, perlu dilakukan pengukuran kondisi lingkungan termasuk keadaan daerah, suhu dan kelembaban untuk menjadi bukti bahwa usaha menurunkan angka kejadian perlu segera digalakkan. Sementara itu, Kabupaten Karo belum tersedia data mengenai identifikasi dan distribusi Aedes sp. Informasi tersebut dapat digunakan sebagai dasar pencegahan dengue melalui upaya pengendalian populasi Aedes $s p$ sebagai vektor mekanik dengue.

\subsection{Perumusan Masalah}

Berdasarkan uraian diatas dapat dirumuskan masalah sebagai berikut : Apakah ada perbedaan distribusi populasi vektor nyamuk Aedes sp dengan tehnik identifikasi morfologi genus nyamuk Aedes sp dan melihat kareakteristik habitat lingkungan termasuk ketinggian lokasi, suhu udara, kelembaban yang terjadi terhadap transmisi penyakit dengan prevalensi DBD yang ditemukan di lokasi lingkungan penelitian.

\subsection{Tujuan}

\subsubsection{Tujuan Umum :}

Mengetahui distribusi populasi vektor Aedes sp dengan tehnik identifikasi morfologi genus nyamuk Aedes $s p$ dan dapat melihat kareakteristik habitat lingkungan termasuk ketinggian lokasi, suhu udara, kelembaban yang terjadi terhadap transmisi penyakit dengan prevalensi DBD yang ditemukan di lokasi lingkungan

\subsubsection{Tujuan Khusus :}

1. Mengetahui distribusi perbedaan populasi vector Nyamuk Aedes $s p$ dengan tehnik identifikasi nyamuk berdasarkan lokasi penelitian.

2. Mengetahui distribusi Nyamuk Aedes sp berdasarkan ketingian daerah lokasi penelitian. 
3. Mengetahui distribusi Nyamuk Aedes sp berdasarkan suhu udara daerah lokasi penelitian.

4. Mengetahui distribusi Nyamuk Aedes sp berdasarkan kelembaban daerah lokasi penelitian.

\subsection{Manfaat Penelitian.}

Hasil penelitian ini diharapkan bermanfaat dan mampu memberikan informasi, masukan kepada :

\section{Bagi Masyarakat, Puskesmas dan Dinas Kesehatan Kabupaten Karo.}

a. Sebagai sumber data untuk pemantauan distribusi populasi vektor nyamuk Aedes sp dalam penangulangan vektor penyakit dan memberikan informasi untuk pedoman dalam menyusun perencanaan program kesehatan lingkungan masyarakat.

b. Dinas kesehatan dapat mengetahui perbedaan dinamika patogen di alam dan dinamika populasi vektor di lingkungan penelitian dampak dari perubahan lingkungan termasuk ketinggian lokasi, suhu udara, kelembaban yang terjadi terhadap transmisi penyakit tular yang ditemukan di lokasi lingkungan penelitian

\section{Bagi pengembangan ilmu pengetahuan}

a. Memberi tambahan pengetahuan, pengalaman, latihan cara dan proses berpikir secara ilmiah yang langsung peneliti dapatkan di lapangan terutama dalam bidang kesehatan lingkungan masyarakat.

b. Sumber informasi untuk penelitian selanjutnya khususnya terkait studi lapangan dalam bidang kesehatan masyarakat. 


\section{Kerangka Teori}

Menurut Hendrik L.Blun ada 4 faktor yang mempengaruhi status derajat kesehtan masyarakat antara lain Pejamu/host (aktifitas/mobilitas dan kebiasaan hidup)), Agen ( vector nyamuk Aedes sp) Lingkungan /Enviromen ( ketingian lokasi, suhu, kelembaban) dan ketururan.

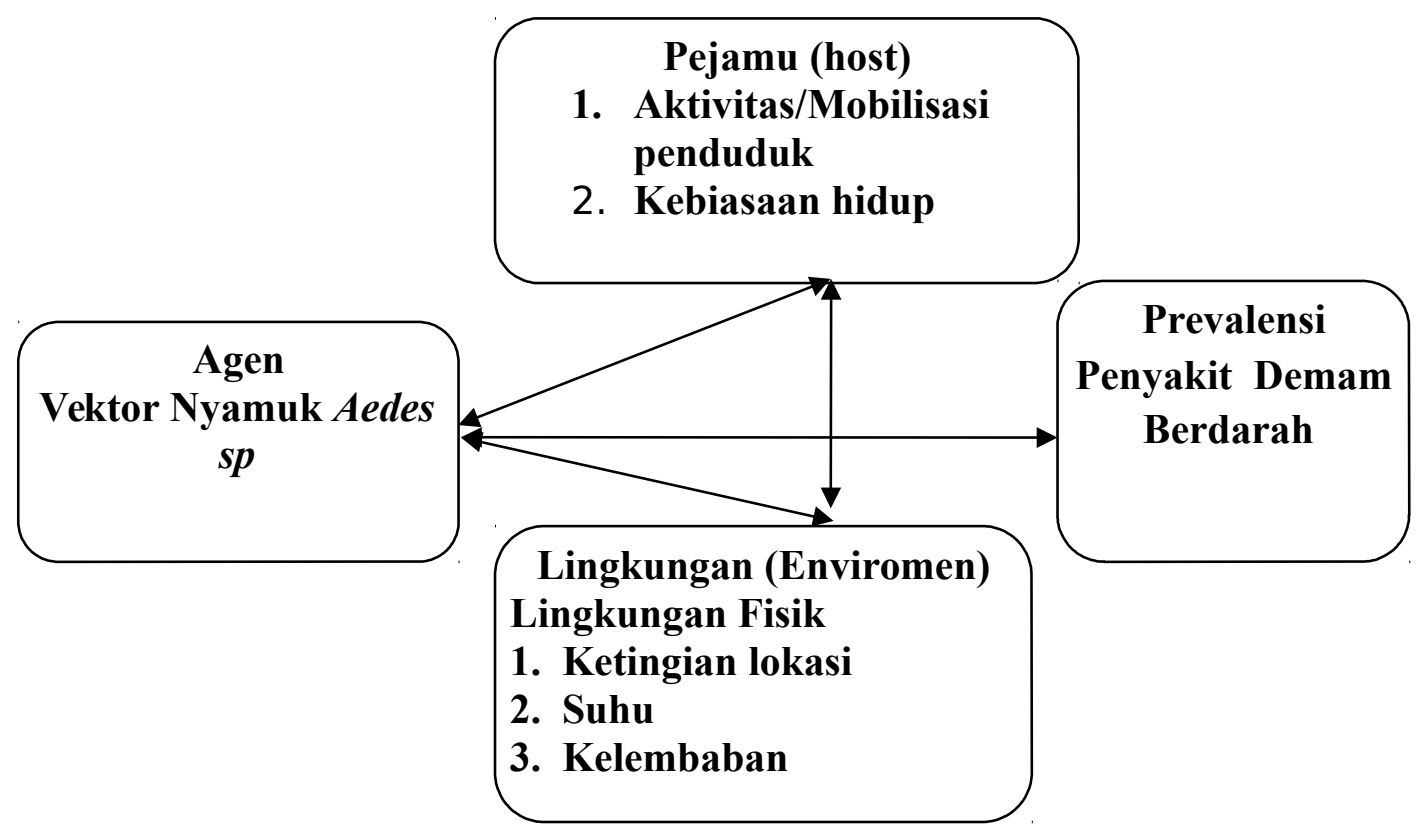

Gambar 2.6. Kerangka Teori

Kerangka Konsep
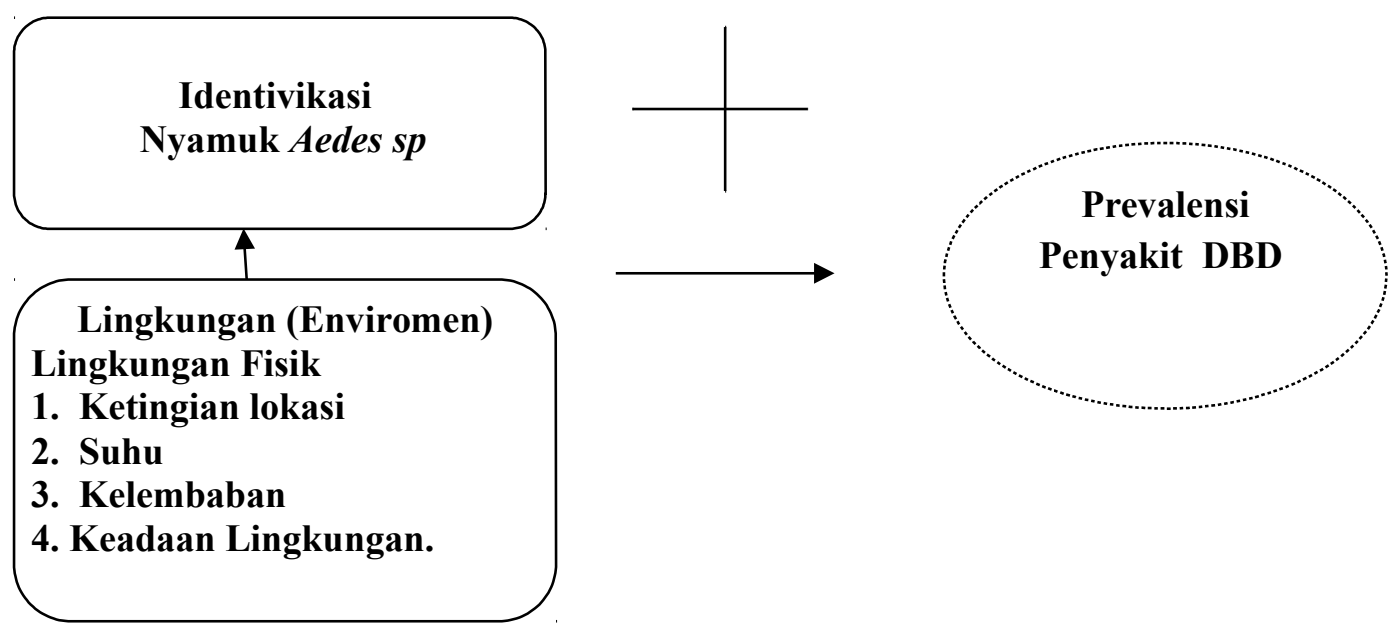

Gambar 2.7 Kerangka Konsep 


\section{BAB III \\ METODE PENELITIAN}

\subsection{Jenis / Rancangan penelitian dan Metode Pendekatan}

Jenis penelitian ini adalah Explanatory Research bersifat deskriptif yaitu melakukan pemeriksaan laboratorium dengan tehnik identivikasi genus nyamuk Aedes $s p$., dan melakukan pengukuran langsung pada titik pemasangan perangkap nyamuk denagn karakteristik habitatnya yaitu ketinggian lokasi, suhu udara, dan kelembaban di lokasi penelitian. Distribusi nyamuk Aedes sp dengan data status prevalensi penyakit DBD di Kabupaten Karo tahun 2017.

\subsection{Lokasi dan waktu Penelitian}

Penelitian di laksanakan di beberapa daerah Kabupaten Karo yang terdiri dari 3 Kecamatan yaitu Kecamatan Berastagi, Kecamatan Kabanjahe dan Kecamatan Merek, terpilih lokasi karena merupakan daerah prevalensi penyakit DBD pada tahun 2017, (Dinas Kesehatan Kabupaten Karo, 2017) sedangkan waktu penelitian akan dilakukan pada bulan Januari - Oktober 2018.

\subsection{Populasi dan Sampel}

1. Populasi

Populasi dalam penelitian ini adalah nyamuk Aedes sp yang ada di beberapa Kecamatan di Kabupaten Karo yang berdasarkan data prevalensi penyakit DBD pada tahun 2017) Data Dinas Kesehatan Kabupaten Karo.

2. Sampel

Karena jumlah nyamuk Aedes sp di suatu tempat tidak dapat diketahui secara pasti maka pengambilan sampel dilakukan dengan pemasangan perangkap nyamuk Masquinotrap (alat perangkap nyamuk sederhana). Jumlah Kecamatan yang berdasarkan data prevalensi penyakit DBD di Kabupaten Karo terdiri dari 3 Kecamatan ( Kecamatan Kabanjahe, Kecamatan Merek, Kecamatan Berastagi). Untuk masing-masing kategori diambil semua kelurahan ataupun desa yang merupakan prevalensi penyakit DBD pada tahun 2017. Penentuan dari titik lokasi berdasarkan data dari Dinas Kesehatan Kabupaten Karo Tahun 2017 mengenai prevalensi penyakit DBD. Untuk mengambil sampel nyamuk Aedes sp, 
maka tiap kelurahan/desa yang kategori prevalensi penyakit DBD dipasang berdasarkan jumlah rumah yang dinyatakan prevalensi penyakit DBD sebanyak 3 Masquinotrap (perangkap nyamuk sederhana) disetiap rumah dipasang didalam rumah dan di luar rumah selama 1 minggu.

Variabel yang diteliti antara lain: genus nyamuk Aedes sp, ketinggian lokasi, suhu udara, kelembaban, keadaan lingkungan

\subsection{Definisi Operasional}

a. Identifikasi Nyamuk adalah dapat melihat ciri-ciri bentuk tubuh nyamuk dengan melihat organ tubuh yang di identifikasi dengan mengunakan mikroskop dan buku kunci identifikasi spesies nyamuk aedes sp dewasa menggunakan kunci identifikasi Borror, serta penelusuran literatur dengan menelaah buku dan artikel tentang DBD, pedoman survei entomologi.

b. Nyamuk Aedes sp adalah phylum arthropoda yang merupakan genus nyamuk Aedes sp, terdapat beberapa jenis nyamuk termasuk Aedes aegypti maupun Aedes albopictus. Aedes aegypti lebih berperan dalam penularan penyakit ini, karena hidupnya di dalam dan di sekitar rumah, sedangkan Aedes albopictus di kebun, sehingga lebih jarang kontak dengan manusia.

c. Masquino trap adalah jenis perangkap nyamuk sederhana yang dirakit dengan menggunakan botol/wadah perangkap dibubuhi umpan sejenis larutan gula serta bubuk ragi untuk merangsang nyamuk hinggap di perangkap.

d. Suhu udara adalah temperatur udara di dalam rumah yang terukur sesuai dengan waktu pengukuran. Rata-rata suhu harian yang berpengaruh terhadap waktu perkembangan nyamuk adalah $25^{\circ} \mathrm{C}$ sampai suhu $30^{\circ} \mathrm{C}$. Kondisi suhu udara yang mendukung penularan DBD jika suhu udara antara $25^{\circ} \mathrm{C}-30^{\circ} \mathrm{C}$ dan tidak mendukung jika suhu udara $<25^{\circ} \mathrm{C}$ atau $>30^{\circ} \mathrm{C}$. Skala pengukuran: Ordinal.

e. Ketinggian tempat adalah letak suatu tempat pada ketinggian tertentu dari atas permukaan laut. Nyamuk Aedes Aegypti hidup di dataran rendah dengan iklim tropis sampai subtropis, nyamuk dapat berkembang biak dengan baik sampai ketinggian \pm 1000 meter dpl, ketinggian lebih dari 1000 meter karena biasanya daerah tersebut memiliki suhu udara yang rendah nyamuk Aedes sp tidak dapat hidup 
f. Kelembaban udara adalah banyaknya kandungan uap air dalam udara di dalam rumah yang dinyatakan dalam faranhait $\left({ }^{0} \mathrm{~F}\right)$. Kelembaban optimal yang diperlukan untuk pertumbuhan nyamuk adalah berkisar antara $60^{\circ} \mathrm{F}-80^{\circ} \mathrm{F}$. Kelembaban yang mendukung penularan DBD jika kelembaban udara antara $60^{\circ} \mathrm{F}-80^{\circ} \mathrm{F}$ dan tidak mendukung jika kelembaban udara $<60^{\circ} \mathrm{F}$ atau $>80^{\circ} \mathrm{F}$, Skala pengukuran: Ordinal.

g. Keadaan lingkungan adalah gambaran keadaan lingkungan disekitar lokasi pemasangan perangkap nyamuk yang memungkinkan tempat perkembangbiakan nyamuk Aedes $s p$.

\subsection{Metode Pengumpulan data (Prosedur Penelitian )}

\section{Tehnik Pengumpulan Data}

Data penelitian diperoleh dari berbagai sumber sebagai berikut:

a. Data Primer

Data dikumpulkan dengan mengambil sampel nyamuk yang telah ditangkap dari 3 Kecamatan di Kabupaten Karo dengan cara memasang perangkap Masquinotrap (perangkap nyamuk sederhana) di lokasi penelitian. Masquinotrap dipasang pada 3 titik Kecamatan yang dijadikan sampel. Pemasangan perangkap dilakukan hanya satu kali di setiap lokasi penelitian selama 1 minggu dan di ukur suhu, kelembaban, dataran tinggi lokasi penelitian. Nyamuk yang terperangkap di bawa ke laboratorium untuk diidentifikasi morfologi nyamuk.

b. Data sekunder berupa ketinggian lokasi, suhu udara, kelembaban di lakukan pengukuran langsung di lokasi penelitian.

\section{Prosedur Penelitian.}

\section{a. Instrumen dan Cara Pengumpulan Data.}

1. Mosquito trap (Perangkap nyamuk sederhana)

2. Alat untuk Identifikasi Nyamuk.

\section{b. Survey Nyamuk}

1. Memasang masqiunotrap di lokasi penelitian.

2. Menempatkan masqiunotrap pada tempat yang terlindung dari air hujan di luar rumah dan didalam rumah. 
3. Diukur keadaan lokasi, suhu, kelembaban, dataran tinggi lokasi penelitian.

4. Masqinotrap yang telah terpasang dicek setelah satu minggu

5. Jika terdapat nyamuk segera dibawa ke laboratorium untuk di identifikasi.

\section{c. Instrumen Alat, bahan dan cara identifikasi}

1. Alat, (Ditjen PPM\&PL, Depkes RI. 2001)

a. Stereo/dissecting mikroskop, untuk identifikasi nyamuk

b. Kotak nyamuk, untuk menyimpan spesimen nyamuk

a. Pinset serangga, untuk memegang nyamuk

b. Cawan petri, untuk tempat nyamuk yang akan diperiksa

c. Punch, untuk menggunting kertas

d. Jarum pin, untuk tempat kertas pinning

\section{Bahan, (Ditjen PPM\&PL, Depkes RI, 2001)}

a. Paper cup/gelas kertas, untuk wadah nyamuk hidup

b. Kain kasa, untuk penutup paper cup

c. Karet gelang, untuk mengikat kain kasa paper cup

d. Jarum serangga no. 3, untuk pinning nyamuk

e. Kertas gambar, untuk membuat point

f. Kloroform, untuk mematikan nyamuk

g. Kutek jernih, untuk merekatkan nyamuk pada point

h. Naftalen/kamper, untuk pengawetan nyamuk

\section{Cara identifikasi, (Ditjen PPM\&PL, Depkes RI, 1996)}

a. Nyamuk ditempelkan pada kertas segitiga dimana sebelumnya kertas tersebut yang ditusuk dengan jarum pin

b. Points adalah kertas tebal dengan cara digunting atau dengan alat punch. Hasilnya berupa kertas kecil bentuk segitiga dengan ukuran tinggi $0,75 \mathrm{~cm}$ dan alas $0,2 \mathrm{~cm}$.

c. Samping kiri nyamuk direkatkan pada point. Dengan cara ini mesonotum letaknya paling jauh dari jarum. Tanda - tanda pada dada nyamuk bagian punggung tampak jelas dan kaki dapat diperiksa dari atas. Secara 
d. Ujung runcing point dibengkokkan ke bawah dengan pincet/kuku ibu jari. Lambung dada kanan direkatkan pada ujung point yang membengkok, letak nyamuk dengan punggung di atas, jadi seperti di lem.

e. Apabila sayap membujur sejajar abdomen,sentuhlah sayap dengan jarum, sehingga sayap seperti posisi terbang.

f. Nyamuk siap di identifikasi.

g. Untuk membuat alat perangkap nyamuk

\section{d. Prosedur Pembuatan Perangkap Nyamuk (Masquinotrap)}

\section{Siapkan bahan dan alat}
a. Botol plastic minuman ukuran 2 liter
b. Air hangat $200 \mathrm{ml}$, Gula pasir 50 gram
c. Bubuk ragi kering 1 gram
d. Isolasi atau alat perekat lainnya, Pisau potong
e. Plastik hitam atau kertas hitam

\section{Cara Kerja Pembuatan Perangkap Nyamuk.}

a. Belah botol $\square$ lastic menjadi dua bagian. Kira-kira potong pada sepertiga dari bagian atas. Agar hasilnya rapi, gambar terlebih dahulu garis pola melingkar sebagai bantuan supaya saat memotong botol tidak acak-acakan.

b. Masukkan gula pasir ke dalam air hangat yang kita siapkan tadi.

c. Lalu campurkan bubuk ragi yag kita siapkan tadi ke dalam air dan aduk hingga bubuk ragi bercampur rata dengan air. Dan taruh sedikit bubuk ragi pada bagian atas cairan tanpa diaduk, tujuannya untuk menghasilkan C02 sebagai penarik perhatian nyamuk supaya $\square$ lasti dan masuk ke dalam perangkap.

d. Taruh potongan bagian atas botol ke dalam botol dengan posisi terbalik dengan bagian corong berada di bawah.

e. Rekatkan botol dengan tutup botol bagian bawah dengan isolasi.

f. Bungkus botol dengan $\square$ lastic hitam atau kertas hitam mengelilingi botol. 


\subsection{Tehnik Pengolahan dan Analisa Data.}

\subsubsection{Pengolahan Data.}

Data yang dihasilkan dalam penelitian ini adalah identifikasi menggunakan mikroskop dan buku kunci identifikasi spesies nyamuk Aedes sp dewasa menggunakan kunci identifikasi Borror, (Borror, D.J., 1996) dan Ditjen PPM\&PL,Depkes RI, 2002, serta penelusuran literatur dengan menelaah buku dan artikel tentang DBD dan pedoman survei entomologi dan menarasikan pengukuran di lingkungan dan perubahan lingkungan termasuk ketinggian lokasi, suhu udara, kelembaban dan keadaan lingkungan yang terjadi terhadap transmisi penyakit yang ditemukan di loakasi lingkungan penelitian.

\subsubsection{Analisa Data}

Data yang diperoleh akan dianalisa secara deskriptif berdasarkan identifikasi morfologi yang diamati seperti probosis, antena, palpus, thorak sayap, abdomen, dan kakinya. Kemudian disusun dalam suatu tabel, deskripsi, dan gambar. Identifikasi menggunakan mikroskop dan buku kunci identifikasi spesies nyamuk Aedes sp menggunakan kunci identifikasi Borror, (Borror, D.J., 1996) dan Ditjen PPM\&PL,Depkes RI, 2002, serta penelusuran literatur dengan menelaah buku dan artikel tentang DBD dan pedoman survei entomologi dan menarasikan pengukuran di lingkungan dan perubahan lingkungan termasuk ketinggian lokasi, suhu udara, kelembaban dan keadaan lingkungan yang terjadi terhadap transmisi penyakit yang ditemukan di loakasi lingkungan penelitian menjasi data pendukung untuk mendeskripsikan tempat perindukan nyamuk. 


\section{BAB IV \\ HASIL DAN PEMBAHASAN}

\subsection{HASIL PENELITIAN}

\subsubsection{Gambaran Umum Kabupaten Karo berdasarkan profil Tahun 2017.}

Secara Geografis letak Kabupaten Karo Berada diantara $2^{0} 50-3^{0} 19^{0}$ Lintang Utara dan $97^{0} 55-98^{0} 38^{\circ}$ Bujur Timur dengan luas 2.127,25 Km2 atau 2,97 persen dari luas Propinsu Sumatera Utara. Kabupaten Karo terletak pada jajaran Bukit Barisan dan sebagian besar wilayahnya merupakan dataran tinggi. Dua gunung berapi aktif terletak di wilayah ini sehingga rawan gempa vukanik. Wilayah Kabupaten Karo berada pada ketinggian 200-1.500 M di atas permukaan laut. Sebelah Utara berbatasan dengan Kabupaten Langkat dan Kabupaten Deli Serdang, sebelah Selatan dengan Kabupaten Dairi dan Toba Samosir, sebelah Timur dengan Kabupaten Deli Serdang dan Kabupaten Simalungung dan sebelah Barat dengan Propinsi Nangroe Aceh Darusalam.

Iklim Kabupaten Karo beriklim tropis dan mempunyai dua musim yaitu musim hujan dan musim kemarau. Musim hujan pertama mulai bulan agustus sampai dengan bulan januari dan musim kedua pada bulan Maret sampai dengan bulan Mei, sedangkan musim kemarau biasanya pada bulan Februari , Juni dan Juli. Suhu udara berkisar antara $15,6^{\circ} \mathrm{C}$ sampai dengan $23,0^{\circ} \mathrm{C}$ dengan kelembaban udara rata-rata 89,12 persen

\subsubsection{Distribusi Nyamuk Aedes sp Dengan Tehnik Identifikasi Nyamuk}

\section{Berdasarkan Lokasi Penelitian.}

Identivikasi di laksanakan di Laboratorium Poltekkes Medan Jurusan Kesehatan Lingkungan setelah pemasangan perangkap di lokasi penelitian dan nyamuk yang tertangkap di bawa ke laboratorium. Jumlah total populasi nyamuk yang berhasil ditangkap dalam penelitian ini ada 1290 ekor. Dari jumlah tersebut, hanya 106 yang merupakan Aedes sp, sementara sisanya adalah nyamuk dari genus dan spesies lain, bahkan beberapa kali ditemukan serangga lain di dalam perangkap. Setelah dilakukan proses identifikasi menggunakan mikroskop dan buku kunci identifikasi nyamuk, hanya ditemukan dua jenis spesies Aedes sp yaitu Aedes Aegipty dan Aedes Abopiktus. 
Berdasarkan hasil penangkapan nyamuk dengan menggunakan masquinotrap di lokasi penelitian,dengan rata-rata Aedes Aegipty 6.77\% dan Aedes Abopiktus 5.09\%. Spesies yang paling banyak ditemukan adalah Aedes Aegiptys, yaitu sebanyak 59 ekor dan Aedes Albopiktus adalah 47 ekor. Penyebaran disetiap Kecamatan adalah Kecamatan Berastagi 15 species Nyamuk Aedes sp degan rincian Aedes Albopiktus 4 ekor dan Aedes Agipty 11 ekor, Kecamatan Kabanjahe 58 species nyamuk Aedes sp yang tertangkap degan rincian Aedes Albopiktus 27 ekor dan Aedes Agipty 31 ekor. Kecamatan Merek 33 species nyamuk Aedes sp yang tertangkap degan rincian Aedes Albopiktus 16 ekor dan Aedes Agipty 17 ekor. Selain Aedes Agipty ditemukan juga spesies nyamuk lainya Culex, Anopeles di semua lokasi penangkapan, baik di dalam rumah maupun diluar rumah. Hasil dapat dilihat pada Tabel 1.

Tabel 1. Spesies Nyamuk Aedes sp yang Ditemukan Berdasarkan Lokasi Penangkapan

\begin{tabular}{ccccc}
\hline No & & Lokasi Penelitian & \multicolumn{2}{c}{$\begin{array}{c}\text { Spesies Nyamuk Aedes sp } \\
\text { yang ditemukan }\end{array}$} \\
\cline { 3 - 5 } & & & Aedes & $\begin{array}{c}\text { Aedes } \\
\text { Aegipty }\end{array}$ \\
\cline { 3 - 5 } & Kecamatan & Kelurahan & Albopiktus & Aegin \\
\hline 1. & Berastagi & Gundalin & 4 & 11 \\
\hline 2. & Kabanjahe & Lau Cimba & 9 & 4 \\
& & Gung Negri & 4 & 11 \\
& & Gung Leto & 8 & 1 \\
& & Komplek RW & 0 & 1 \\
& & Komplek RSU & 0 & 5 \\
\hline 3. & Merek & Kampung Dalam & 6 & 17 \\
\hline & & Desa Tongging & 16 & 59 \\
\hline
\end{tabular}

\subsubsection{Distribusi Nyamuk Aedes sp Berdasarkan Ketingian Daerah.}

Berdasarkan hasil penangkapan nyamuk dengan menggunakan masquinotrap di lokasi penelitian,dengan rata-rata ketingian daerah 1208.15 mdpl yang di ukur langsung mengunakan altimeter di lokasi penelitian setelah meletakkan perangkap masquinotrap dengan ketingian daerah $1208.15 \mathrm{~m}$ dpl yang diukur di temukan nyamuk Aedes sp 8 ekor dengan rincian Aedes Aegipty 3 ekor dan Aedes Albopiktus 5 ekor. Jumlah Nyamuk Aedes sp dengan ketinggian daerah terendah 913 - 1100 m dpl, ditemukan 32 ekor nyamuk Aedes sp. dengan rincian Aedes 
Aegipty 16 ekor dan Aedes Albopiktus 16 ekor, ketinggian daerah tertingi 1290 1996 m dpl, ditemukan 28 ekor nyamuk Aedes sp. dengan rincian Aedes Aegipty 17 ekor dan Aedes Albopiktus 11 ekor. Species nyamuk Aedes sp terbanyak di terdapat pada ketingian 913 - 1100 dengan jumlah nyamuk Aedes sp adalah 32 ekor dengan rincian Aedes Aegipty 16 ekor dan Aedes Albopiktus 16 ekor. Hasil dapat dilihat pada Tabel 2

Tebel 2. Distribusi Nyamuk Aedes Sp. Berdasarkan

Ketinggian

\begin{tabular}{cccc}
\hline No & $\begin{array}{c}\text { Ketingian Daerah } \\
\text { Ketingian } \\
(\text { mdpl) }\end{array}$ & \multicolumn{2}{c}{$\begin{array}{c}\text { Spesies Nyamuk Aedes sp yang } \\
\text { ditemukan }\end{array}$} \\
\cline { 3 - 4 } & $913-1100$ & 16 & Aedes Aegipty \\
\hline 1. & $1151-1183$ & 5 & 16 \\
\hline 2. & $1196-1202$ & 10 & 6 \\
\hline 3. & $1207-1280$ & 5 & 3 \\
\hline 4. & $1290-1996$ & 11 & 17 \\
\hline 5. & Total & 47 & 59 \\
\hline
\end{tabular}

\subsubsection{Distribusi Nyamuk Aedes sp Berdasarkan Suhu Udara.}

Berdasarkan hasil penangkapan dilokasi penelitian ditemukan nyamuk Aedes $s p$ dengan menggunakan masquinotrap di lokasi penelitian,dengan rata-rata suhu $27^{\circ} \mathrm{C}$ yang di ukur langsung pada saat meletakkan masquinotrap menggunakan thermometer suhu dengan suhu $27^{\circ} \mathrm{C}$ didapat nyamuk Aedes sp 61 ekor dengan rincian Aedes Aegipty 36 ekor dan Aedes Albopiktus 25 ekor. Jumlah Nyamuk Aedes sp dengan suhu terendah $<25^{\circ} \mathrm{C}$, ditemukan 20 ekor nyamuk Aedes sp. dengan rincian Aedes Aegipty 10 ekor dan Aedes Albopiktus 10 ekor, suhu tertingi $>30^{\circ} \mathrm{C}$ ditemukan species nyamuk Aedes sp 25 ekor dengan rincian Aedes Aegipty 13 ekor dan Aedes Albopiktus 12 ekor, dan species nyamuk Aedes sp terbanyak di dapat pada suhu $25,0^{\circ} \mathrm{C}-30,0^{\circ} \mathrm{C}$ ditemukan species nyamuk Aedes sp 61 ekor dengan rincian Aedes Aegipty 36 ekor dan Aedes Albopiktus 25 ekor. Hasil dapat dilihat pada Tabel 3 
Tabel 3. Distribusi Nyamuk Aedes Sp. Berdasarkan Suhu Udara

\begin{tabular}{|c|c|c|c|}
\hline \multirow[t]{2}{*}{ No } & \multirow{2}{*}{$\begin{array}{l}\text { Suhu } \\
\left({ }^{0} \mathrm{C}\right)\end{array}$} & \multicolumn{2}{|c|}{$\begin{array}{c}\text { Spesies Nyamuk Aedes sp yang } \\
\text { ditemukan }\end{array}$} \\
\hline & & Aedes Albopiktus & Aedes Aegipty \\
\hline 1. & $<25$ & 10 & 10 \\
\hline 2. & $25-30$ & 25 & 36 \\
\hline 3. & $>\mathbf{3 0}$ & 12 & 13 \\
\hline 4. & Total & 47 & 59 \\
\hline
\end{tabular}

\subsubsection{Distribusi Nyamuk Aedes sp Berdasarkan Kelembaban Daerah.}

Berdasarkan hasil penangkapan nyamuk dengan menggunakan masquinotrap di lokasi penelitian,dengan rata-rata kelembaban daerah $73,90^{\circ} \mathrm{F}$ dengan nyamuk Aedes sp 65 ekor dengan rincian Aedes Aegipty 37 ekor dan Aedes Albopiktus 28 ekor. Nyamuk Aedes sp dengan kelembaban daerah terendah $<60^{\circ} \mathrm{F}$, ditemukan 2 ekor nyamuk Aedes sp. dengan rincian Aedes Aegipty 2 ekor dan Aedes Albopiktus 0 ekor, Kelembaban daerah tertingi $>80^{\circ} \mathrm{F}$ ditemukan 39 ekor nyamuk Aedes sp. dengan rincian Aedes Aegipty 20 ekor dan Aedes Albopiktus 19 ekor. Species nyamuk Aedes $s p$ terbanyak di dapat pada kelembaban $60-80^{\circ} \mathrm{F}$, ditemukan 65 ekor nyamuk Aedes sp. dengan rincian Aedes Aegipty 37 ekor dan Aedes Albopiktus 28 ekor. Hasil dapat dilihat pada Tabel 4.

Tabel 4. Distribusi Nyamuk Aedes Sp. Berdasarkan Kelembaban Udara

\begin{tabular}{cccc}
\hline No & Kelembaban & \multicolumn{2}{c}{$\begin{array}{c}\text { Spesies Nyamuk Aedes sp yang } \\
\text { ditemukan }\end{array}$} \\
\cline { 3 - 4 } & $\left({ }^{0} \mathrm{~F}\right)$ & Aedes Albopiktus & Aedes Aegipty \\
\hline 1. & $<60$ & $\mathbf{0}$ & 2 \\
\hline 2. & $60-80$ & 28 & 37 \\
\hline 3. & $>80$ & 19 & 20 \\
\hline & Total & 47 & 59 \\
\hline
\end{tabular}




\section{2 . PEMBAHASAN}

\subsubsection{Distribusi Nyamuk Aedes sp Dengan Tehnik Identifikasi Nyamuk Berdasarkan Lokasi Penelitian.}

Identifikasi Nyamuk dapat melihat ciri-ciri bentuk tubuh nyamuk dengan melihat organ tubuh yang di identifikasi dengan mengunakan mikroskop dan buku kunci identifikasi spesies nyamuk aedes sp dewasa menggunakan kunci identifikasi Borror, serta penelusuran literatur dengan menelaah buku dan artikel tentang DBD, pedoman survei entomologi. Nyamuk Aedes sp adalah phylum arthropoda yang merupakan genus nyamuk Aedes sp, terdapat beberapa jenis nyamuk termasuk Aedes aegypti maupun Aedes albopictus. Aedes Aegypti lebih berperan dalam penularan penyakit ini, karena hidupnya di dalam dan di sekitar rumah, sedangkan Aedes Albopictus di kebun, sehingga lebih jarang kontak dengan manusia. Masquino trap jenis perangkap nyamuk sederhana yang dirakit dengan menggunakan botol/wadah perangkap dibubuhi umpan sejenis larutan gula serta bubuk instan ragi untuk merangsang nyamuk hinggap di perangkap. Perbedaan yang dapat dilihat dari pada Nyamuk Aedes sp adalah morfologi dari nyamuk pada thorak nyamuk dewasa yaitu lyre pada bagian mesonotum Aedes Aegypti dan scutellum trilobus dan garis puth pada median bagian mesonotum Aedes Albopictus .

Pemeriksaan sampel nyamuk Aedes Aegypti dan Aedes Albopictus dalam penelitian ini merupakan salah satu upaya untuk mengetahui tingkat kepadatan dan penyebaran populasi kedua spesies tersebut di suatu wilayah penelitian. Pengetahuan mengenai persebaran vektor virus dengue sangat penting untuk memahami transmisi penyakit DBD antar populasi manusia karena pengaruhnya terhadap transfer patogen tersebut. Hasil penelitian menunjukkan bahwa jumlah total nyamuk Aedes sp dari semua lokasi penelitian di Kabupaten Karo berdasarkan populasi prevalensi penyakit DBD data tahun 2017 yang dilakukan menggunakan perangkap nyamuk Masquinotrap yang diletakkan di dalam rumah dan diluar rumah secara keseluruhan adalah 106 ekor, dengan jumlah nyamuk Aedes Aegipti adalah 59 ekor dan Aedes Albopiktus adalah 47 ekor. 
Hasil penelitian dari ketiga Kecamatan di Kabupaten Karo dapat dirinci bahwa di Kecamatan Berastagi ditemukan nyamuk Aedes sp 14 ekor dengan rincian Aedes Aegipti 11 ekor dan Aedes Albopiktus 4 ekor. Hasil penelitian ini dipengaruhi dengan prevalensi data penyakit DBD di daerah berastagi dan juga dipengaruhin oleh keadaan lokasi diperkotaan ataupun keadaan suhu dan kelembaban udara yang rendah, dengan jumlah Aedes Aegipti 11 ekor ini sangat berpengaruh dengan daerah pemukiman yang ada diperkotaan dan Aedes Albopiktus 4 ekor ini depengaruhi dengan prevalensi penyakit DBD masih didominasi didaerah perkotaan dan merupakan daerah wisata yang berpengaruh dengan adanya mobilitas penduduk yang masuk dan keluar ke daerah wisata. Perkembangbiakan nyamuk Aedes Albopiktus di daerah berastagi dipengaruhi masih terdapatnya daerah pertanian di daerah prevalensi penyakit DBD karena perkembangbiakan Aedes Albopiktus terdapat pada dahan pepohonan yang dapat menampung air bersih.

Kecamatan Kabanjahe 58 species nyamuk Aedes sp yang tertangkap degan rincian Aedes Albopiktus 27 ekor dan Aedes Agipty 31 ekor. sangat berpengaruh dengan daerah pemukiman yang ada diperkotaan sebagai daerah ibukota Kabupaten Karo dengan prevalensi penyakit DBD terbanyak dijumpai di Kabupaten Karo yang berada di Kecamatan Kabanjahe dan dapat juga dipengaruhi oleh mobilitas penduduk dengan tingkat perdaganngan hasil pertanian yang tinggi sebagai pusat pasar di daerah Kabupaten Karo. Aedes Albopiktus 27 ekor ini depengaruhi dengan prevalensi penyakit DBD dan pemukiman masyarakat berkisar didaerah makam pahlawan yang ada di Kabanjahe yang memungkinkan perkembangbiakan nyamuk Aedes Abopiktus berada di daerah perkebunan yang dapat menampung air hujan pada pelepah dahan pohon.

Kecamatan Merek 33 species nyamuk Aedes sp yang tertangkap degan rincian Aedes Albopiktus 16 ekor dan Aedes Agipty 17 ekor. Nyamuk Aedes Agipti sangat berpengaruh dengan mobilatas penduduk karena daerah Merek merupakan daerah wisata Danau Toba. Aedes Albopiktus 27 ekor ini depengaruhi dengan prevalensi penyakit DBD dan pemukiman masyarakat berkisar didaerah Pertanian dan masih dijumpai daerah hutan lindung yang ada di Merek yang memungkinkan perkembangbiakan nyamuk Aedes Abopiktus berada di daerah 
Hutan lindung dan perkebunan yang dapat menampung air hujan pada pelepah dahan pohon.

\subsubsection{Distribusi Nyamuk Aedes sp Berdasarkan Ketingian Daerah.}

Faktor penting yang berpengaruh dan membatasi penyebaran nyamuk Aedes Aegypti adalah ketinggian tempat. Nyamuk Aedes Aegypti hidup di dataran rendah dengan iklim tropis sampai subtropis, nyamuk dapat berkembang biak dengan baik sampai ketinggian \pm 1000 meter dpl, DBD banyak terjadi diketingian dibawah 1000 meter diatas permukaan laut. Dikabupaten Karo dengan ketingian 1000 meter diatas permukaan laut telah ditemukan penderita DBD, secara teori hal ini jarang terjadi.

Berdasarkan hasil penangkapan nyamuk dengan menggunakan masquinotrap di lokasi penelitian,dengan rata-rata ketingian daerah $1208.15 \mathrm{mdpl}$ dengan nyamuk Aedes sp 8 ekor dengan rincian Aedes Aegipty 3 ekor dan Aedes Albopiktus 5 ekor. Aedes. Aegypti biasanya tidak ditemukan di daerah dengan ketinggian lebih dari 1000 meter karena biasanya daerah dengan ketinggian tersebut memiliki suhu udara yang rendah, sehingga tidak memungkinkan bagi nyamuk Aedes Aegypti untuk hidup, namun di Kabupaten Karo dengan ketingian rata-rata 1208.15 ditemukan nyamuk Aedes sp ini yang kemungkinan dipengaruhi dengan perobahan suhu di daerahn mobilitas penduduk yang tinggi akibat daerah wisata dan daerah perdagangan hasil pertanian, penelitian ini sejalan dengan WHO, 2011 bahwa di daerah-daerah tertentu seperti di India, Aedes Aegypti ditemukan pada daerah dengan ketinggian 2121 meter, di Kolombia ditemukan pada ketinggian 2200 meter, dan di Eritrea pada ketinggian 2400 meter dpl (World Health Organization, 2011).

\subsubsection{Distribusi Nyamuk Aedes sp Berdasarkan Suhu Udara.}

Suhu udara yang tinggi menjadi faktor yang meningkatkan laju pertumbuhan nyamuk. Sebaliknya, suhu yang lebih dingin dapat menghambat laju pertumbuhan Nyamuk Aedes sp. Penelitian di Amerika Utara menunjukkan adanya peningkatan kepadatan Aedes Albopictus di musim dingin yang suhunya mulai menghangat sebagai dampak dari perubahan iklim, (Hanson, SM, Craig GB Jr. 1995).

Suhu udara dengan temperatur udara di dalam rumah yang terukur sesuai dengan waktu pengukuran. Rata-rata suhu harian yang berpengaruh terhadap 
waktu perkembangan nyamuk Aedes $s p$ adalah $25^{\circ} \mathrm{C}$ sampai suhu $30^{\circ} \mathrm{C}$. Kondisi suhu udara yang mendukung penularan DBD jika suhu udara antara $25^{\circ} \mathrm{C}-30^{\circ} \mathrm{C}$ dan tidak mendukung jika suhu udara $<25^{\circ} \mathrm{C}$ atau $>30^{\circ} \mathrm{C}$.

Berdasarkan hasil penangkapan nyamuk dengan menggunakan masquinotrap di lokasi penelitian,dengan rata-rata suhu $27^{\circ} \mathrm{C}$ merupakan suhu udara yang mendukung perkembangbiakan nyamuk Aedes $s p$ di dearah penelitian ditemukan nyamuk Aedes sp 61 ekor dengan rincian Aedes Aegipty 36 ekor dan Aedes Albopiktus 25 ekor. Suhu udara di lokasi penelitian sangat berpengaruh dengan perobahan lingkungan dengan kemungkinan dipengaruhi dengan adanya gempa gunung sinabung sehingga perobahan suhu menjadi meningkat dan perobahan lingkungan dari daerah pertanian menjadi daerah pemukiman yang tinggi. Namun nyamuk Aedes sp dengan suhu terendah $<25^{\circ} \mathrm{C}$, masih ditemukan 20 ekor nyamuk Aedes sp. dengan rincian Aedes Aegipty 10 ekor dan Aedes Albopiktus 10 ekor yang memungkinkan terjadinya mobilitas penduduk, Kondisi suhu udara yang mendukung penularan DBD jika suhu udara antara $25^{\circ} \mathrm{C}-30^{\circ} \mathrm{C}$ suhu yang sangat mendukung perkembangbiakan nyamuk Aedes $s p$ pada lokasi penelitian ini ditemukan species nyamuk Aedes sp 61 ekor dengan rincian Aedes Aegipty 36 ekor dan Aedes Albopiktus 25 ekor, suhu udara $>30,0^{\circ} \mathrm{C}$ juga ditemukan species nyamuk Aedes sp 25 ekor dengan rincian Aedes Aegipty 13 ekor dan Aedes Albopiktus 12 ekor yang kemungkinan terjadi akibat mobilitas penduduk yang masuk dan keluar ke daerah penelitian.

\subsubsection{Distribusi Nyamuk Aedes sp Berdasarkan Kelembaban.}

Kelembaban udara merupakan banyaknya kandungan uap air dalam udara di dalam rumah yang dinyatakan dalam faranhait $\left({ }^{0} \mathrm{~F}\right)$. Kelembaban optimal yang diperlukan untuk pertumbuhan nyamuk Aedes sp adalah berkisar antara $60^{\circ} \mathrm{F}-$ $80^{\circ} \mathrm{F}$. Kelembaban yang mendukung penularan DBD jika kelembaban udara antara $60^{\circ} \mathrm{F}-80^{\circ} \mathrm{F}$ dan tidak mendukung jika kelembaban udara $<60^{\circ} \mathrm{F}$ atau $>$ $80^{\circ} \mathrm{F}$

Berdasarkan hasil penangkapan nyamuk dengan menggunakan masquinotrap di lokasi penelitian,dengan rata-rata kelembaban daerah 73,90\% yang merupakan kelembaban optimal yang diperlukan untuk pertumbuhan nyamuk Aedes $s p$ dengan nyamuk Aedes sp 65 ekor dengan rincian Aedes Aegipty 37 ekor dan 
Aedes Albopiktus 28 ekor. Hasil penelitian tersebut sangat mendukung dengan kelembaban rata-rata $73,9^{\circ} \mathrm{F}$. Tidak mendukung jika kelembaban udara $<60^{\circ} \mathrm{F}$, ditemukan 2 ekor nyamuk Aedes sp. dengan rincian Aedes Aegipty 2 ekor dan Aedes Albopiktus 0 ekor, atau $>80 \%$. Pada penelitian ini kelembaban daerah tertingi $>80^{\circ} \mathrm{F}$ ditemukan 39 ekor nyamuk Aedes sp. dengan rincian Aedes Aegipty 20 ekor dan qqAedes Albopiktus 19 ekor. Species nyamuk Aedes sp terbanyak di dapat pada kelembaban $60-80^{\circ} \mathrm{F}$, ditemukan 65 ekor nyamuk Aedes sp. dengan rincian Aedes Aegipty 37 ekor dan Aedes Albopiktus 28 ekor. Species nyamuk Aedes sp dengan kelembaban yang tinggi $>80^{\circ} \mathrm{F}$ di daerah penelitian kemungkinan dipengaruhi karena adanya perubahan kaedaan lingkungan dengan adanya gempa gunung sinabung. 


\section{BAB V}

\section{KESIMPULAN DAN SARAN}

\subsection{KESIMPULAN}

1. Species Aedes sp yang teridentifikasi dari 3 Kecamatan di Kabupaten Karo ada 106 species nyamuk Aedes sps. Spesies Nyamuk dengan rata-rata Aedes Aegipty 6.77\% dan Aedes Abopiktus 5.09\%. Spesies yang paling banyak ditemukan adalah Aedes Aegipty, yaitu sebanyak 59 ekor dan Aedes Albopiktus adalah 47 ekor

2. Penangkapan nyamuk Aedes $s p$ di lokasi penelitian,dengan rata-rata ketingian daerah 1208.15 mdpl dengan nyamuk Aedes sp 8 ekor dengan rincian Aedes Aegipty 3 ekor dan Aedes Albopiktus 5 ekor dan ketinggian daerah terendah 913 - 1100 m dpl, ditemukan 32 ekor nyamuk Aedes sp.

3. Rata-rata suhu yang didapat pada penelitian ini yang diukur langsung dilokasi pada saat meletakkan perangkap adalah $27^{\circ} \mathrm{C}$ dengan nyamuk Aedes sp 61 ekor dengan rincian Aedes Aegipty 36 ekor dan Aedes Albopiktus 25 ekor dan Nyamuk Aedes sp dengan suhu terendah $<25^{\circ} \mathrm{C}$, ditemukan 20 ekor nyamuk Aedes sp, suhu tertingi $>30^{\circ} \mathrm{C}$ ditemukan species nyamuk Aedes sp 25 ekor

4. Berdasarkan hasil penangkapan nyamuk dengan rata-rata kelembaban daerah 73,90 ${ }^{\circ} \mathrm{F}$ dengan nyamuk Aedes sp 65 ekor dengan rincian Aedes Aegipty 37 ekor dan Aedes Albopiktus 28 ekor, kelembaban $<60^{\circ} \mathrm{F}$, ditemukan 2 ekor nyamuk Aedes $s p$ dan tertingi $>80^{\circ} \mathrm{F}$ ditemukan 39 ekor nyamuk Aedes $s p$. 


\subsection{SARAN}

Berdasarkan hasil penelitian ini, maka dapat diberikan saran-saran sebagai berikut:

1.

Perlu dilakukan peningkatan kebersihan lingkungan dari setiap Kecamatan dan Kelurahan yang dapat menyebabkan perkembang biakan nyamuk Aedes sp terutama pada daerah prevalensi penyakit DBD di Kabupaten Karo.

2.

Tehnik Identivikasi agar lebih teliti pada saat pemeriksaan dibawah stereo mikroskop khusus untuk identivikasi nyamuk dan menguasai perbedaan titik morfologi jenis nyamuk Aedes sp.

3.

Melestarikan Lingkungan hidup untuk mempertahankan normalnya suhu dan kelembaban pada daerah lokasi ketinggian diatas 1000 m dpl di Kabupaten Karo.

4.

Sangat perlu diadakan survai lapangan dalam perubahan suhu, kelembaban dengan menggunakan data prevalensi penyakit DBD setiap tahun untuk mendapatkan data yang lebih representatif dengan cakupan yang lebih luas sehingga dapat memberikan data mengenai kepadatan nyamuk Aedes $s p$ vektor DBD di Kabupaten Karo

5.

Perlu adanya peningkatan perhatian seluruh pihak baik lembaga pemerintah dan masyarakat dalam upaya penanggulangan nyamuk Aedes sp sebagai agen potensial penyebaran penyakit dalam rangka peningkatan kualitas kesehatan masyarakat secara terpadu dan berkelanjutan.

6.

Perlu dilakukan penelitian lanjutan tentang pengaruh karakter nyamuk Aedes sp akibat perubahan lingkungan termasuk suhu, kelembaban, ketingian daerah di Kabupaten Karo. 


\section{DAFTAR PUSTAKA}

Borror, D.J., Triplehorn, C.A., Johnson, N.F. 1996. Pengenalan pelajaran serangga. Edisi keenam. Terjemahan. Gadjah Mada University Press, Yogyakarta. Hal: 670-671.

Depkes RI. (1992.a). Petunjuk Teknis Pemberantasan Nyamuk Penular Penyakit Demam Berdarah Dengue. Jakarta : Dirjen PPM dan PLP.

Depkes RI. (1992.b). Petunjuk Teknis Pengamatan Penyakit Demam BerdarahDengue. Jakarta : Dirjen PPM dan PLP.

Dep.Kes RI. Ditjen PPM \& PLP. 2002. Pedoman Ekologi dan Aspek Perilaku Vektor. Jakarta

Depkes RI (2004) Tatalaksana Demam Berdarah (DBD) di Indonesia, Dirjen PPM dan PL, Departemen Kesehatan Republik Indonesi, Jakarta.

Dinas Kesehatan Propinsi Sumut, (2005), Profil Kesehatan Profinsi Sumatera Utara, Medan

Dinas Kesehatan kota Medan, 2003, Profil Kesehatan Medan, Medan

Dinas Kesehatan Kabupaten Karo, 2005, Profil Kesehatan Kabupaten Karo, Kabupaten Karo.

Ditjen PPM\&PL, Depkes RI. Pedoman survai entomologi malaria. Jakarta : Depkes RI; 2001.

Ditjen PPM\&PL, Depkes RI. Pengamatan serangga penular penyakit. Jakarta : Depkes RI; 1996.

Fathi, Soedjajadi Keman, dan Chatarina Umbul Wahyuni. 2005. Peran faktor lingkungan dan perilaku terhadap penularan demam berdarah dengue di kota Mataram. Jurnal kesehatan lingkungan. 2(1):1-10.

Foster WA, Walker ED. Medical and Veterinary Entomology. Edited by Gary Mullen dan Lance Durden. London: Academic Press. 2002. p 203-233

Hanson, SM, Craig GB Jr. 1995. Cold acclimation, diapause, and geographic origin affect cold hardiness in eggs of Aedes albopictus (Diptera: Culicidae). Journal of Medical Entomology, 31(2):192-201.

Kementerian Kesehatan RI. 2012. Profil Data Kesehatan Indonesia Tahun 2011, Jakarta, hal 71,101. 
McCall, J, and Pattamaporn Kittayapong. 2006. Control of dengue vectors: tool and strategies. Scientific Working Group, Report on Dengue, Geneva, 1-5 October 2006.

Moraes, EC, Sergio H Franchito, and V Brahmananda Rao. 2013. Impact of Global Warming on the energy balance and climate. 52(3), (http://journals.ametsoc.org/doi/abs/10.1175/JAMC-D-11-0258.1, diakses 23 Juli 2013).

Rueda LM. Zootaxa. Pictorial Keys for the Identification of Mosquitoes (Diptera: Culicidae) Associated with Dengue Virus Transmission. Auckland, New Zealand: Mongolia Press. 2004.

Scott TW, Morrison AC. Aedes aegypti Density and the Risk of Dengue Virus Transmission. Chapter 14 2003. p.187-206. http://library.wur.nl/frontis/ malaria/14_scott.pdf. diakses 20 November 2007

World Health Organization. Pencegahan dan Pengendalian Dengue dan Demam Berdarah Dengue. Panduan Lengkap. Alih bahasa: Palupi Widyastuti. Editor Bahasa Indonesia: Salmiyatun. Cetakan I. Jakarta: Penerbit Buku Kedokteran EGC. 2005. hal $58-77$ 